\title{
Screening and Characterization of Achromobacter xylosoxidans isolated from rhizosphere of Jatropha curcas L. (Energy Crop) for plant-growth-promoting traits
}

\author{
Preeti Vyas ${ }^{1}$, Damendra Kumar², Anamika Dubey ${ }^{1}$ and Ashwani Kumar ${ }^{1 *}$
}

${ }^{1}$ Metagenomics \& Secretomics Research laboratory, Department of Botany, Dr.Harisingh Gour University (A Central University), Sagar (M.P.), India

${ }^{2}$ Department of Biotechnology, Dr. Harisingh Gour University (A Central University), Sagar (M.P.), India

Received: July 26, 2018; Accepted: August 1, 2018; Published: August 6, 2018

*Corresponding author: Ashwani Kumar, Assistant Professor, Metagenomics \& Secretomics Research laboratory, Department of Botany, Dr.Harisingh Gour University (A Central University), Sagar (M.P.) India, Tel: 91-7697432012, E-mail id: ashwaniiitd@hotmail.com

\begin{abstract}
Plant growth promoting rhizobacteria (PGPR) colonizes almost all the ecological niches in and around the plant roots and enhances plant growth and show profound impact upon plants productivity. In the present study we have isolated large number of bacterial isolates from the rhizosphere of non-edible oil seed plant Jatropha curcas (Common name: Physic nut; Family: Euphorbiaceae). Out of large number of isolates we have selected only four bacterial isolates (AKDJ1, AKDJ2, AKDJ3, and AKDJ4) on the basis of their multifarious PGP traits (bioflim production, ammonia production, indole acetic acid (IAA), phosphate solubilization, catalase enzyme and cellulase enzyme production). Out of four, the isolate AKDJ2 was characterized by various biochemical utilization tests (Citrate, lysine, ornithine, urease, phenylalanine, H2S production, nitrate reduction, glucose, lactose, adonitol, sorbitol, arabinose, and 35 different carbohydrate sources) and identified as Achromobacter xylosoxidans (Gene bank Accession no KX698100) which showed 99\% similarity with Achromobacter xylosoxidans strain NBRC15126 by using $16 \mathrm{~S}$ rDNA sequencing. We conclude that, bacterial isolates screened from the rhizosphere of plant could serve as a source of potential biofertilizer for improving the production of same and other crops under variety of stress conditions.
\end{abstract}

Keywords: Plant growth promoting rhizobacteria; Biofertilizer; 16S rDNA; Energy crop

\section{Introduction}

Jatropha curcas L. belongs to family Euphorbiaceae is a perennial, drought resistant, and multipurpose oil seed plant. It is often recognized as an potential source for future biodiesel production [1-4]. Jatropha curcas is a tropical plant and grow in wastelands, areas with low precipitation. Jatropha can be grown in boundaries to protect agriculture fields from grazing and soil erosion or they can be planted in the farms as a commercial crop. To improve its growth and production for biofuel generation, a number of agricultural management practice have been used by several researchers in the past. Kumar et al.[2,5-9] used different bioinoculants to improve its growth and yield under saline and alkaline soil conditions. The bioinoculants used in previous studies are commonly screened and isolated from rhizosphere and commonly known as plant growth promoting rhizobacteria (PGPR). These PGPR promote plant growth and suppresses disease incidence which is solely resulted due to the synergistic effect of nutrients and phytohormones produced by these bacteria [10-12]. Bioinoculation of selected PGPR with seeds of Jatropha can improve growth of plant by providing resistance to plants towards different abiotic and biotic stress conditions. PGPR are often used for improving fertility and facilitates establishment of plant [13-15]. Great efforts have been made to investigate the beneficial role of PGPR on crop production under variety of stress conditions [16-20]. PGPR can stimulate plant growth by using direct and indirect mechanism of action. Direct mechanism of PGPR action includes fixation of atmospheric nitrogen, phosphate solubilization, Siderophore production, and production of plant hormones (like Auxins and Cytokines). Indirect mechanism of plant growth stimulation includes synthesis of some plant growth substances or facilitating the uptake of certain nutrients [21].

Soil is most dynamic and complex system that supports overall growth of the plant. The abiotic and biotic stresses are the major constrain for sustainable agricultural production. Most of these microbes are dependent upon different root exudates secreted by plants for their survival [21]. Evidences supports the fact that plants utilizes greater amount of nutrients that are present in the soil in modern intensive cultivation and often needs replenishment of the nutrients. Under these conditions microbes offers a good alternative strategy to replenish various nutrients. Kumar et al. (2015b) in his study isolated one hundred and six PGPR bacteria from the rhizosphere and endosphere of Hippophae rhamnoides L. (Sea-buckthorn). Theses bacterial isolates were then screened for different PGP traits. Results of their study showed $76.41 \%$ of bacterial isolates, depict IAA or auxin production activity, $43.39 \%$ of bacterial isolates depicts siderophore activity and $19.4 \%$ of bacterial isolates shows HCN production activity. 
The objectives of the present study was to isolate bacterial strains from the rhizosphere of the Jatropha curcas, and characterized them for morphological and physiological attributes as well as identify them by using $16 \mathrm{~S}$ rDNA sequencing. Graphical representation of work done is presented in Figure 1.

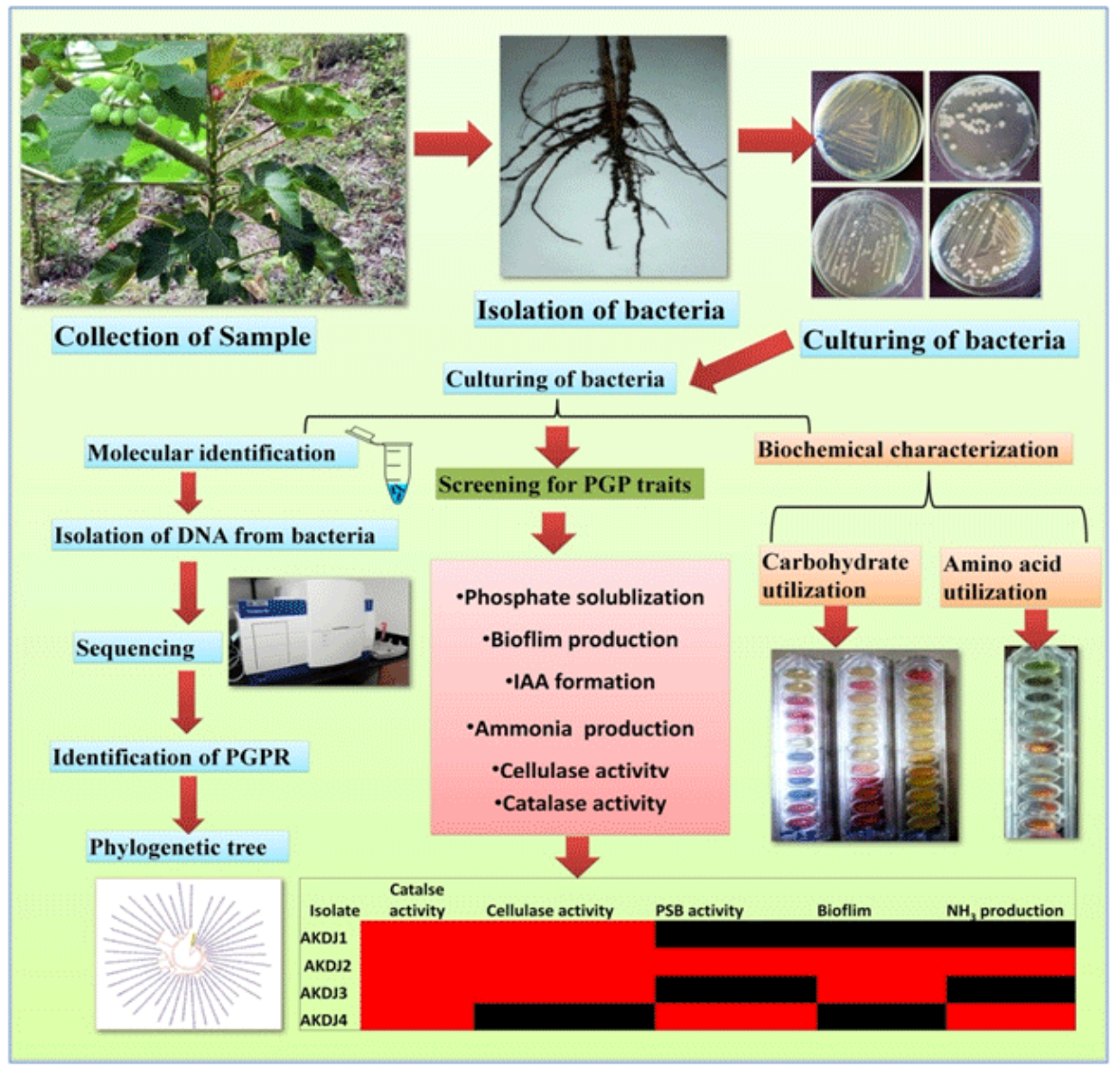

Figure 1: Flow chart of experimental work

\section{Materials and methods}

\section{Collection of samples}

The rhizosphere soil sample was collected from the Botanical garden located at Dr. Harisingh Gour University Sagar (M.P), India.
The location of the site is at $23^{\circ} 49^{\prime} 34 \mathrm{~N}$ latitude and $78^{\circ} 46^{\prime} 35 \mathrm{E}$ longitude as shown in Figure 2. The rhizosphere soil was often collected after digging in depth up to $15 \mathrm{~cm}$. These samples were placed in sterile polythene bags and brought to the lab. And stored at $4^{\circ} \mathrm{C}$ in refrigerator until use

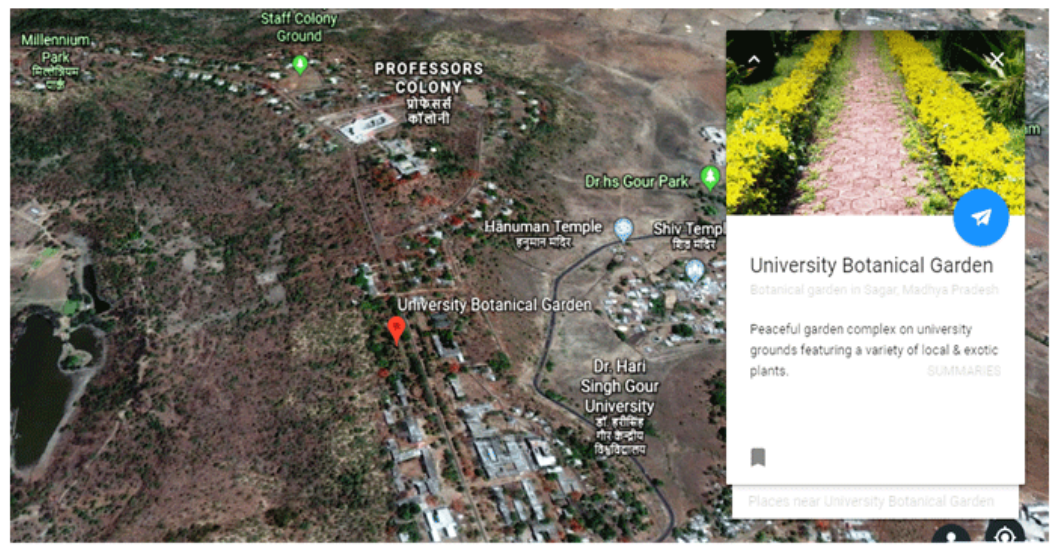

Figure 2: Sample collection site (Google earth image)

Citation: Preeti Vyas, Damendra Kumar, Anamika Dubey, Ashwani Kumar (2018) Screening and Characterization of Achromobacter xylosoxidans isolated from rhizosphere of Jatropha curcas L. (Energy Crop) for plant-growth-promoting traits. J Adv Res Biotech 


\section{Isolation of Rhizobacteria from the rhizosphere}

For isolation of bacteria, $1 \mathrm{~g}$ of rhizospheric soil was used and was plated on nutrient agar media (Peptone $10 \mathrm{~g} / \mathrm{L}, \mathrm{NaCl} 5.0 \mathrm{~g} / \mathrm{L}$, Yeast extract $10 \mathrm{~g} / \mathrm{l}, 1 \mathrm{M} \mathrm{NaOH}, 10 \mathrm{ml} / \mathrm{l}$, Agar15g/l at $\mathrm{pH}$ 7). The plates were then incubated for about $24 \mathrm{hrs}$ at $28{ }^{\circ} \mathrm{C}$ for further experiment. These bacterial isolates were further maintained at liquid nutrient broth and preserved in glycerol at $-20^{\circ} \mathrm{C}$

\section{Morphological and biochemical characterization}

Morphological characterization of each bacterial isolates was examined on nutrient agar plates. Three days old culture of bacterial isolates were used for determining the size, color, shape, surface, elevation, and margin of colonies. The Grams staining of the isolated strains was also carried out to find out the gram positive and gram negative strain as described by Vincent and Humphrey [23]. Light microscopy was used to observe the size and motility of the bacterial cell. Biochemical and carbohydrate test was conducted by using kits (KB002 HiAssortedTM Biochemical Test Kit and HiCarbohydrateTM Test kit KB009), respectively.

\section{Molecular identification of potential bacteria and bioinformatic analysis}

Total genomic DNA was successfully extracted from bacteria isolates by using Insta Gene TM Matrix Genomic DNA isolation kit. Final concentration of DNA was determined by using nano drop and visualized by running DNA gel electrophoresis. Isolated DNA was PCR amplified by using universal 27F forward primers with sequence (AGAGTTTGATCMTGGCTCAG) and 1492R reverse primer with sequence (TACGGTACCTTGTTACGACTT). The PCR reaction was performed by using the method presented in Vyas et al. (2018). PCR products were then purified and sequenced using an ABI Big Dye Terminator v3.1 cycle sequencing kit (Applied Biosystems, Grand Island, NY, USA). Obtained sequences were then compared with other sequences through NCBI BLAST at http://www.ncbi.n1m.nih.gov/blast/Blast.cgi. Sequences were submitted to NCBI GenBank data base and obtained accession numbers (Accession number: KX698100). The phylogenetic analysis of sequences with the closely related sequence of NCBI blast results was performed by following multiple sequence alignment. A phylogenetic tree for these bacterial sequences were constructed by using iTOL (Interactive tree of life) after establishing relationship among the similar sequences analysis generated from Mega 5.05 software [27, 28].

\section{Biochemical Assays}

\section{Solubilization of Insoluble Phosphate}

$200 \mu \mathrm{L}$ of bacterial suspension was spot inoculated at the centre phosphate solubilizing agar plates or Pikovaskay's plate [24]. The plates were then incubated at $28^{\circ} \mathrm{C}$ for about 5 days and halos' zones produced were measured indicating varying levels of phosphate solubilisation.

\section{Ammonia production}

This test is based on the production of urease which break urea into ammonia and which in turn increase the $\mathrm{pH}$ of the medium. Freshly grown cultures of bacterial isolates were inoculated into urea broth containing peptone and incubated at $37^{\circ} \mathrm{C}$ for $24 \mathrm{hrs}$. Bacterial culture was then centrifuged. $1 \mathrm{ml}$ of Nessler's reagent was added to the supernatant and change in color yellow to brown was a positive test for ammonia production.

\section{Production of Indole-3-Acetic Acid}

Bacterial cultures were grown on Dev tryptophan broth [25] on rotatry shaker at $37^{\circ} \mathrm{C}$ for 5 days. Bacterial suspension was then centrifuged at $1000 \mathrm{rpm}$ for $20 \mathrm{~min}$. $1 \mathrm{ml}$ of Salkowsky's reagent was added to $1 \mathrm{ml}$ of supernatant and incubated in dark incubator for $1 \mathrm{~h}$. Then, development of pink color considered positive for IAA production and further measured at $536 \mathrm{~nm}$ by using microplate reader.

\section{Bioflim formation}

In this, ability of PGPR to form biofilm on root surface will be assayed using CV (crystal violet) by following standard protocol. For this assay bacterial isolates will be grown in nutrient broth and incubated at $37^{\circ} \mathrm{C}$ for 3 days. After incubation, samples were further stained by using $1 \%$ crystal violet solution and extracted with ethanol. The crystal violet stain will be then spectrophotometrically quantified by measuring the absorbance at 690 nm.

\section{Catalase activity}

$1 \mathrm{ml}$ of bacterial culture taken into tubes and add few drop of H2O2 separately. The evolution of oxygen in the form of bubble indicates positive reaction for catalase production.

\section{Cellulase activity}

Cellulase production was determined by using the standard protocols. Agar medium $\left(\mathrm{NaNO}_{3}, \mathrm{~K}_{2} \mathrm{HPO}_{4}, \mathrm{MgSO}_{4}, \mathrm{KCl}\right.$, Sodium $\mathrm{CMC}$, peptone and Agar) with yeast extract plates were inoculated with individual bacterial isolates and incubated for 3-5 days at $28^{\circ} \mathrm{C}$. Bacterial growth surrounded by clear halos was considered as positive indication of cellulose production. The incubated CMC agar plates were then flooded with grams iodine solution allowed to stand for $1 \mathrm{~min}$ at room temperature. $1 \mathrm{M} \mathrm{NaCl}$ was thoroughly used for counter staining the plates. Clear halos zones were observed around growing bacterial colonies indicating hydrolysis of cellulose [26].

\section{Results and Discussion}

In this present study total of 4 bacterial isolates were successfully isolated from the rhizosphere of non-edible oil seed plant Jatropha curcas. These four bacterial isolates (AKDJ1, AKDJ2, AKDJ3, and AKDJ4) were identified morphologically on the basis of size, color, shape, surface, elevation, and margin, of colonies. The Grams staining was performed most of the bacterial species were grams negative. These bacterial isolates 
were further screened for different plant growth promoting traits (bioflim production, ammonia production, indole acetic acid (IAA), phosphate solubilization, and catalase and cellulase production). Out of the four isolates (AKDJ1, AKDJ2, AKDJ3, AKDJ4), two isolates formed biofilm (AKDJ2, AKDJ3). Biofilm formation by rhizobacteria is an important trait, with respect to their beneficial activity. Two bacterial isolates (AKDJ3, AKDJ4) showed positive result for ammonia production as shown in Figure 3. Two bacterial isolates(AKDJ2, AKDJ4) shows formation of clear halos zone when inoculated at PSB agar medium as shown in Figure 4. Two isolates showed positive result for IAA activity (AKDJ3, AKDJ4). All the four bacterial isolates (AKDJ1, AKDJ2, AKDJ3, AKDJ4), showed catalase activity as shown in Figure 5. Three bacterial isolates (AKDJ1, AKDJ2, and AKDJ3) showed cellulase producing activity as shown in Figure 6.

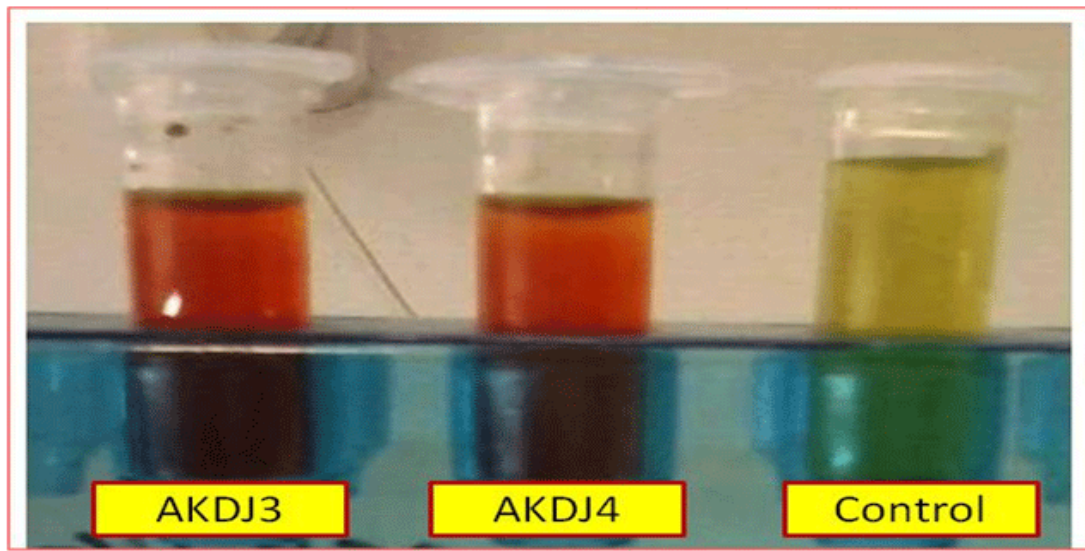

Figure 3: Bacterial isolates showing ammonia production activity

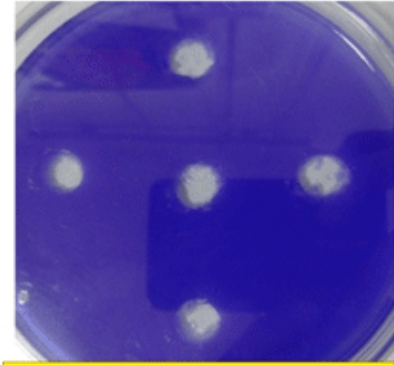

Control

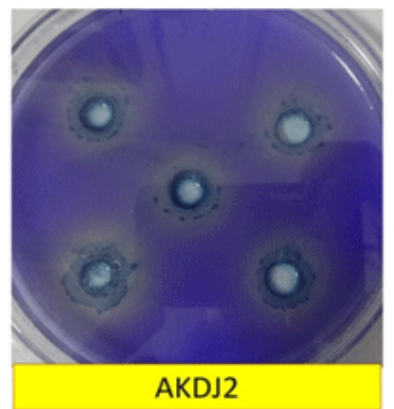

AKDJ2

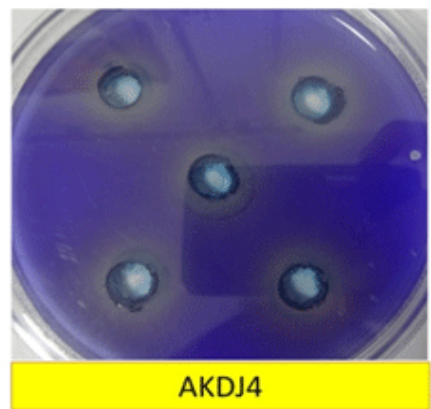

Figure 4: Bacterial isolates showing phosphate solubilizing activity

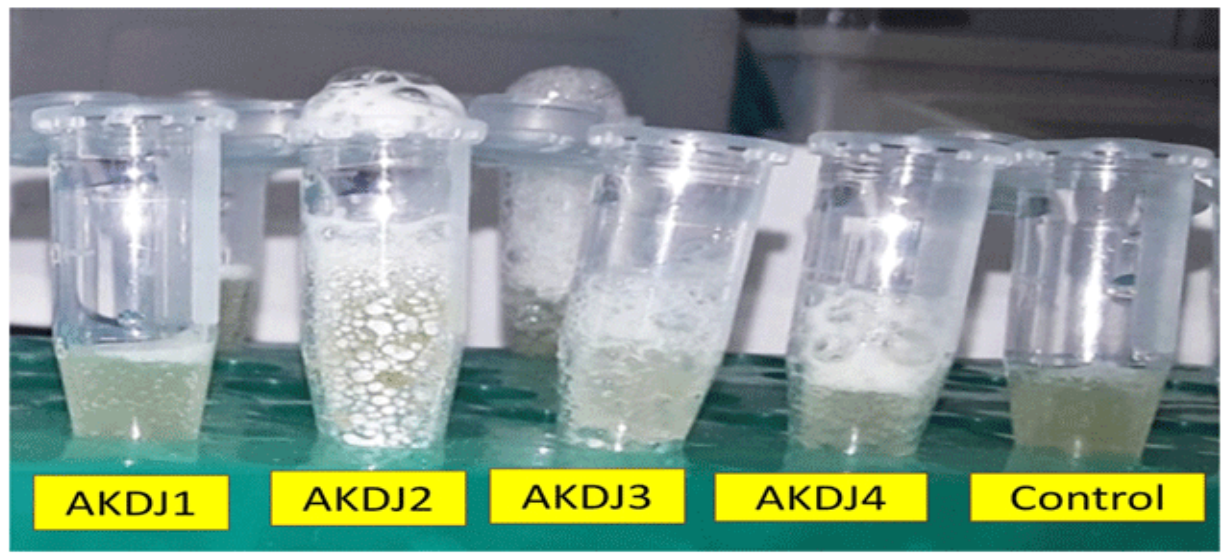

Figure 5: Bacterial isolates showing catalase activity

Citation: Preeti Vyas, Damendra Kumar, Anamika Dubey, Ashwani Kumar (2018) Screening and Characterization of Achromobacter xylosoxidans isolated from rhizosphere of Jatropha curcas L. (Energy Crop) for plant-growth-promoting traits. J Adv Res Biotech 


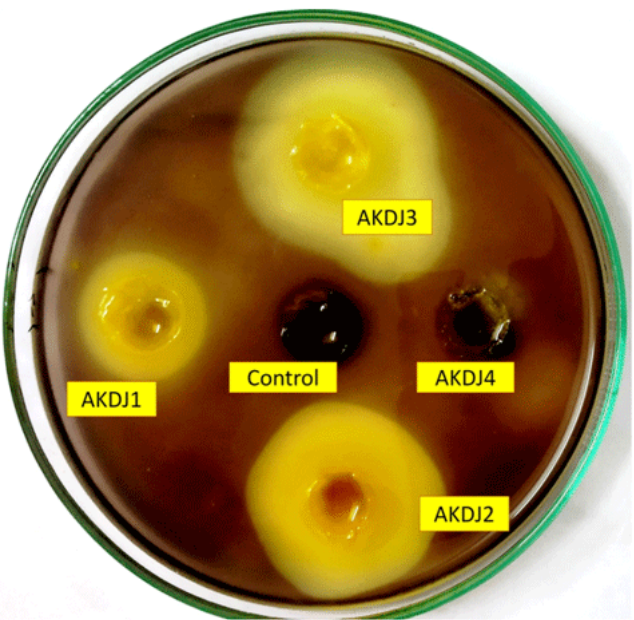

Figure 6: Bacterial isolates showing cellulase producing activity

Biochemical characterization test were performed for isolates AKDJ2. This isolate show positive result for orinithine, urease, nitrate reductase, Adonitol, lactose and sorbitol utilization and show negative result for citrate utilization, lysine utilization, phenylalanine deamination, $\mathrm{H}_{2} \mathrm{~S}$, glucose and arabinose utilization. This bacterial isolates (AKDJ2) characterized biochemically for 35 carbohydrates sources and showed positive test for 24 carbohydrate sources and negative for 11 carbon sources and utilized 7 biochemicals out of 12, as shown in Table 1 and Table 2.

Table 1: Utilization of carbohydrates by AKDJ2

\begin{tabular}{|c|c|c|}
\hline S No. & Carbohydrate & AKDJ2 \\
\hline 1. & Lactose & Negative \\
\hline 2. & Xylose & Positive \\
\hline 3. & Maltose & Positive \\
\hline 4. & Fructose & Positive \\
\hline 5. & Dextrose & Positive \\
\hline 6. & Galactose & Positive \\
\hline 7. & Raffinose & Positive \\
\hline 8. & Trehalose & Positive \\
\hline 9. & Melibiose & Positive \\
\hline 10. & Sucrose & Positive \\
\hline 12. & Mannose & Negative \\
\hline 13. & Inulin & Negative \\
\hline 14. & Sodium gluconate & Positive \\
\hline 15. & Glycerol & Positive \\
\hline 16. & Salicin & Positive \\
\hline 17. & Dulcitol & Positive \\
\hline 18. & Inositol & Positive \\
\hline 19. & Sorbitol & Positive \\
\hline 20. & Mannitol & Negative \\
\hline 21. & Adinitol & Negative \\
\hline 22. & Arabitol & Negative \\
\hline
\end{tabular}

Citation: Preeti Vyas, Damendra Kumar, Anamika Dubey, Ashwani Kumar (2018) Screening and Characterization of Achromobacter xylosoxidans isolated from rhizosphere of Jatropha curcas L. (Energy Crop) for plant-growth-promoting traits. J Adv Res Biotech 
Screening and Characterization of Achromobacter xylosoxidans isolated from rhizosphere of Jatropha curcas L. (Energy Crop) for plant-growth-promoting traits

\begin{tabular}{|c|c|c|}
\hline 23. & Erythritol & Negative \\
\hline 24. & Methyl-D-glucoside & Positive \\
\hline 25. & Rhamnose & Positive \\
\hline 26. & Cellobiose & Negative \\
\hline 27. & Melezitose & Negative \\
\hline 28. & Methyl-D-mannoside & Positive \\
\hline 29. & Xylitol & Positive \\
\hline 30. & ONPG & Negative \\
\hline 31. & Esculin hydrolysis & Positive \\
\hline 32. & D-Arabinose & Positive \\
\hline 33. & Citrate Utilization & Positive \\
\hline 35. & Malonate utilization & Positive \\
\hline 36. & Sorbose & Negative \\
\hline
\end{tabular}

Table 2: Biochemical Utilization by AKDJ2

\begin{tabular}{|c|c|c|}
\hline S No. & Test & AKDJ2 \\
\hline 1 & Citrate Utilization & Negative \\
\hline 2 & Lysine Utilization & Negative \\
\hline 3 & Ornithine Utilization & Positive \\
\hline 4 & Urease & Positive \\
\hline 5 & Phenlalanine Deamination & Negative \\
\hline 6 & Nitrate reduction & Positive \\
\hline 7 & H S Production & Negative \\
\hline 8 & Glucose & Positive \\
\hline 9 & Adonitol & Positive \\
\hline 10 & Lactose & Positive \\
\hline 11 & Arabinose & Negative \\
\hline 12 & Sorbitol & Positive \\
\hline
\end{tabular}

AKDJ2 was identified as Achromobacter xylosoxidans (Gene bank Accession no KX698100) which showed 99\% similarity with Achromobacter xylosoxidans strain NBRC15126 (Accession number: KX698100) by using 16 S rDNA sequencing. Phylogenetic tree was prepared by using iTOL tool for establishing relationship of this isolate with other closely related genera (Figure 7). 


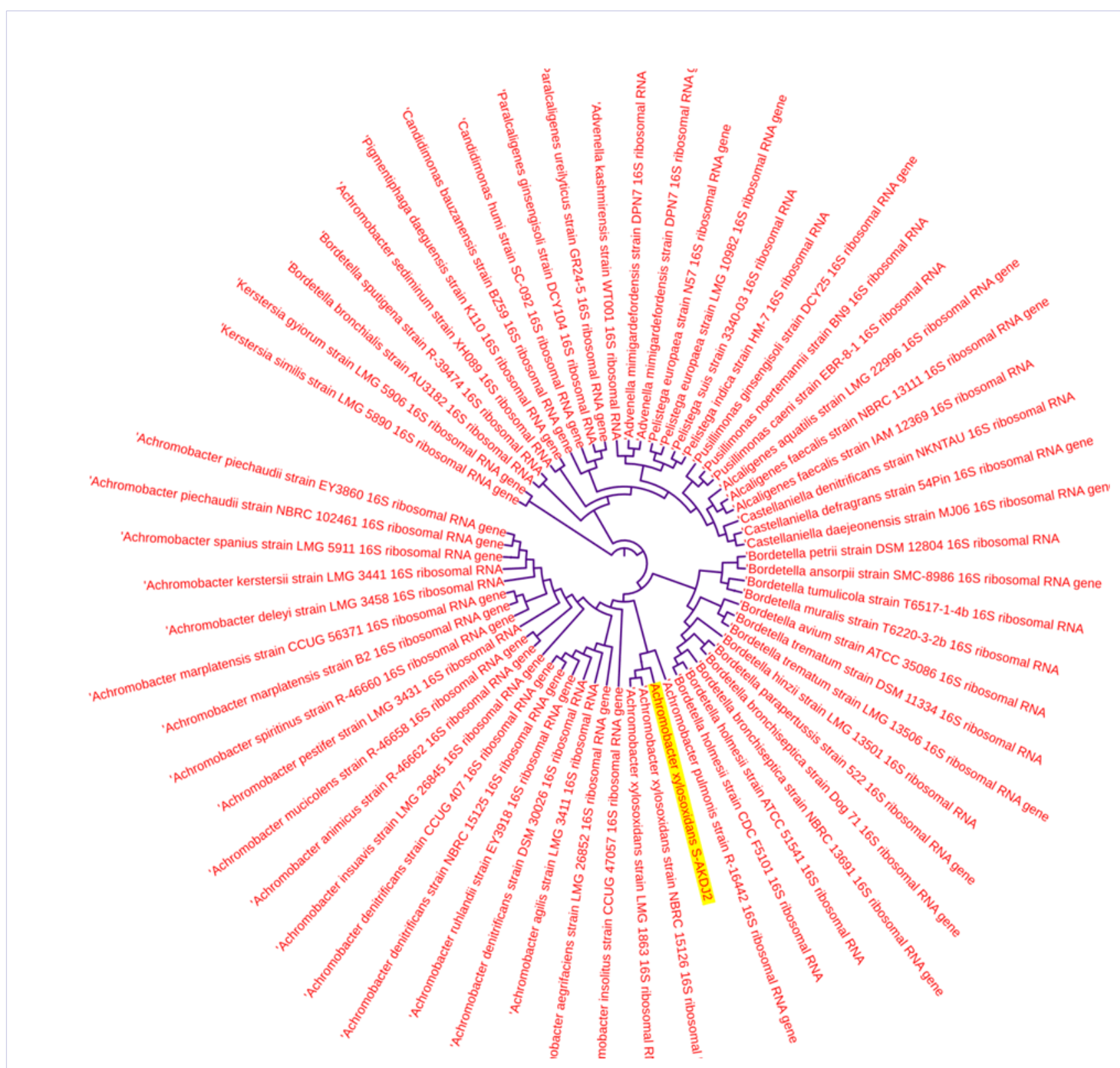

Figure 7: Phylogenetic tree created by iTOL software to present relationship between closely related species of Achromobacter xylosoxidans strain AKDJ2

\section{Conclusions}

PGPR are a group of bacteria that play an important role in plant growth promotion. Screening PGPR from rhizosphere of plants may be viable option to enhance the biomass production on limited soil conditions/marginal land. Additionally the potential isolates may be further utilized as tailor made biofertilizer for promoting growth of the other plants. The application of PGPR instead of chemical fertilizers offers a sustainable, safe, and ecofriendly approach to increase crop production and soil health.

\section{Acknowledgement}

PV acknowledges University fellowship and AK would like to acknowledge the UGC Startup grant (Awarded to AK) for the financial support. 


\section{References}

1. Kumar A, Sharma S. An evaluation of multipurpose oil seed crop for industrial uses (Jatropha curcas L.): A review. Industrial Crops and Products. 2008;28(1):1-10.

2. Kumar A, Kumar K, Kaushik N, Sharma S, Mishra S. Renewable energy in India: Current status and future potentials. Renew Sustain Energy Rev. 2010;14(8):2434-2442. doi: 10.1016/j.rser.2010.04.003

3. Maghuly F, Laimer M. Jatropha curcas, a biofuel crop: Functional genomics for understanding metabolic pathways and genetic improvement. Biotechnology Journal. 2013;8(10):1172-1182.

4. Kumar A, Sharma S. Potential non-edible oil resources as biodiesel feedstock: An Indian perspective. Renew Sustain Energy Rev. 2011;15(4):1791-1800. doi: 10.1016/j.rser.2010.11.020

5. Kumar A, Sharma S, Mishra S. Influence of arbuscular mycorrhizal (AM) fungi and salinity on seedling growth, solute accumulation, and mycorrhizal dependency of Jatropha curcas L. J Plant Growth Regul. 2010;29(3):297-306. doi: 10.1007/s00344-009-9136-1

6. El-Naby SKMA. Effect of banana compost as organic manure on grow th, nutrients status, yield and fruit quality of Maghrabi banana. Assiut J Agric Sci. 2000;31(3):101-114.

7. Kumar A, Dames JF, Gupta A, Sharma S, Gilbert JA, Ahmad P. Current developments in arbuscular mycorrhizal fungi research and its role in salinity stress alleviation : a biotechnological perspective. Crit Rev Biotechnol. 2014;8551:1-14.

8. Kumar A, Sharma S, Mishra S, Dames JF. Arbuscular mycorrhizal inoculation improves growth and antioxidative response of Jatropha curcas (L.) under Na2SO4 salt stress. Plant Biosyst. 2015;149(2):260-269.

9. Kumar A, Sharma S, Mishra S. Evaluating effect of arbuscular mycorrhizal fungal consortia and Azotobacter chroococcum in improving biomass yield of Jatropha curcas. Plant Biosyst. 2016;150(5):1056-1064

10. Hashem A, Fathi E, Allah A, Alqarawi AA, Kumar A. Plant defense approach of Bacillus subtilis ( BERA 71 ) against Macrophomina phaseolina ( Tassi ) Goid in mung bean. J Plant Interact. 2017;12(1) 390-401.

11. Doornbos RF, Van Loon LC, Bakker PAHM. Impact of root exudates and plant defense signaling on bacterial communities in the rhizosphere. A review. Agron Sustain Dev. 2012;32(1):227-243.

12. Barnawal D, Bharti N, Pandey SS, Pandey A, Chanotiya CS, Kalra A. Plant growth-promoting rhizobacteria enhance wheat salt and drought stress tolerance by altering endogenous phytohormone levels and TaCTR1/TaDREB2 expression. Physiol Plant. 2017;161(4):502-514. doi: 10.1111/ppl.12614

13. Igiehon NO, Babalola 00. Rhizosphere Microbiome Modulators Contributions of Nitrogen Fixing Bacteria towards Sustainable Agriculture Int J Environ Res Public Health. 2018;15(4). doi: 10.3390/ijerph15040574
14. Kumar A, Sharma S, Mishra S, Dames JF. Arbuscular mycorrhizal inoculation improves growth and antioxidative response of Jatropha curcas (L.) under Na2So4 salt stress. Plant Biosyst - An Int J Deal with all Asp Plant Biol [Internet]. 2013;149(2):260-269.

15.Dubey A, Kumar A, Abd_Allah EF, Hashem A, Khan ML. Growing more with less: Breeding and developing drought resilient soybean to improve food security. Ecol Indic [Internet]. 2018.

16.Porcel R, Aroca R, Ruiz-Lozano JM. Salinity stress alleviation using arbuscular mycorrhizal fungi. A review. Agronomy for Sustainable Development. 2012;32(1):181-200.

17. Babalola 00. Beneficial bacteria of agricultural importance. Biotechnology Letters. 2010;32(11):1559-1570. doi: 10.1007/ s10529-010-0347-0

18. Lugtenberg B, Kamilova F. Plant-Growth-Promoting Rhizobacteria. Annu Rev Microbiol [Internet]. 2009;63(1):541-556.

19. Miransari M. Plant Growth Promoting Rhizobacteria. J Plant Nutr [Internet]. 2014;37(14):2227-2235.

20.Rengasamy P. Soil processes affecting crop production in saltaffected soils. Functional Plant Biology. 2010;37:613-620

21.Glick BR. Plant Growth-Promoting Bacteria: Mechanisms and Applications. Scientifica. 2012:1-15

22. Kumar A, Guleria S, Mehta P, Walia A, Chauhan A, C.K. S. Plant growth-promoting traits of phosphate solubilizing bacteria isolated from Hippophae rhamnoides L. (Sea-buckthorn) growing in cold desert Trans-Himalayan Lahul and Spiti regions of India. Acta Physiologiae Plantarum. 2015b;37:1-12.

23.Vincent JM, Humphrey B. Taxonomically significant group antigens in Rhizobium. J Gen Microbiol. 1970;63(3):379-382. doi: 10.1099/00221287-63-3-379

24.Sylvester-Bradley R, Asakawa N, La TorracaS, Magalhães FM, Oliveira LA, Pereira RM. Levantamento quantitativo de microrganismos solubilizadores de fosfatos na rizosfera de gramíneas e leguminosas forrageiras na Amazônia. Acta Amaz. 1982;12(1):15-22.

25. Frankenberger WT, Arshad M. Yield Response of Watermelon And Muskmelon To L-Tryptophan Applied To Soil. Hortscience. 1991;26(1):35-37.

26. Chand R, Richa K, Dhar H, Dutt S, Gulati A. A Rapid and Easy Method for the Detection of Microbial Cellulases on Agar Plates Using Gram ' s Iodine. Curr Microbiol. 2008;57(5):503-507. doi: 10.1007/s00284008-9276-8

27. Kimura M. A simple method for estimating evolutionary rates of base substitutions through comparative studies of nucleotide sequences. J Mol Evol. 1980;16(2):111-120.

28.Letunic I, Bork P. Interactive tree of life (iTOL) v3 : an online tool for the display and annotation of phylogenetic and other trees. 2016;44:242-245. doi: 10.1093/nar/gkw290 